\title{
Efficiency of municipal service providers in the Republic of Croatia
}

\author{
Alemka Šegota ${ }^{1}$, Ljerka Cerović $^{1}$ and Dario Maradin ${ }^{1, \dagger}$ \\ ${ }^{1}$ Faculty of Economics, University of Rijeka, Ivana Filipovića 4, 51000 Rijeka, Croatia \\ E-mail: 〈\{alemka.segota, ljerka.cerovic, dario.maradin\}@efri.hr 〉
}

\begin{abstract}
Municipal services, such as the collection, removal and disposal of waste, are just some of the necessary activities carried out by public authorities. Efficient management and utilization of public resources improves the general well-being of a community, and benefits especially the users of municipal services. Hence, the optimal provision of public services is essential. This paper gives a comprehensive overview of municipal services, related primarily to waste collection and disposal, and other related municipal services. The purpose of the paper is to determine the relative cost efficiency of twenty public utility companies that collect household waste in different Croatian cities and surrounding municipalities. The method employed in the study is Data Envelopment Analysis (DEA), using a non-controllable input-oriented model with variable returns to scale. In addition to the relative efficiency results of each utility company, by means of projections on the efficiency frontier, sources and amounts of relative inefficiency were determined, which represent potential improvements for all inefficient utility companies. The results indicate that all inefficient utility companies can improve their efficiency by reducing the corresponding inputs. Thus, company material costs should be drastically reduced, i.e., the relatively inefficient utility company (with the exception of two companies) should reduce costs by at least $50 \%$. Considering employee costs, half of the relatively inefficient utility companies should reduce such costs by up to $50 \%$, while the other half should reduce those costs by $58.11 \%$ to about $70 \%$. Furthermore, five of the inefficient companies should reduce total assets input by a relatively small amount (up to $38.00 \%$ ), whereas the remaining seven companies should reduce the company's total assets from $60.96 \%$ to $70.99 \%$. This means that management at inefficient companies take into account the obtained results when making decisions in the future in order to increase company efficiency, which is one of the characteristics of an optimal business.
\end{abstract}

Keywords: public municipal service providers, relative efficiency, DEA method

Received: March 02, 2017; accepted: October 03, 2017; available online: December 30, 2017

DOI: $10.17535 /$ crorr. 2017.0035

\footnotetext{
$\dagger$ Corresponding author
} 


\section{Introduction}

The management of municipal services, such as, waste collection, treatment and disposal, is an important aspect in the operations of public authorities, despite relatively low expenditures for such services compared to other public services. It is the public authorities that are generally thought to perform waste collection, although it may be provided in a variety of ways, i.e., through public-private partnerships. There are considerable differences between models for collecting household and industrial waste. Unlike residential waste, commercial and industrial entities vary considerably in the amount of waste they produce, which is why waste is collected almost daily, whereas larger industrial entities ensure independent collection, disposal and management of waste. On the other hand, collection and disposal of household waste includes the regular and planned transfer of waste of animal and vegetable origins produced in processing and serving foods and drinks, as well as various combustible and non-combustible solid wastes, excluding bulk waste.

Evaluating the relative efficiency of the operations of public authorities becomes important when searching for an optimal model of functioning for public authorities that provide various services, offering quality solutions to achieve greater efficiency. Citizens themselves are taking a greater interest in public spending and subsequently in efficient public services. In considering specific segments of activities undertaken by public authorities in Croatia, this paper analyses public municipal services, which includes the collection, removal and disposal of household waste. This approach is based on evaluating the relative efficiency of public utility companies in Croatia using a method called Data Envelopment Analysis. The method uses multiple inputs and one output as well as non-controllable input-oriented model with variable returns to scale.

The purpose of the paper is to determine the relative cost efficiency of 20 public utility companies that collect household waste in the Republic of Croatia using the Data Envelopment Analysis method, and based on data from the year 2014. The research aim is to identify sources and amounts of the relative inefficiency of utility companies and identify paths to improve service performance.

\section{Research sample: selection criteria, principles, scope}

Municipal services in the Republic of Croatia are provided as public services. Although utility companies deliver a variety of municipal services, due to the demands and limitations of methodology, i.e., the need to compare and evaluate only those companies that operate in similar conditions and offer the same core service, the scope of analysis in this paper covers 20 public utility companies in Croatia fulfilling certain criteria. Furthermore, due to the organization and size 
of the companies, the study does not include utility companies that operate only in certain municipalities and major cities in the Republic of Croatia. After excluding companies that fail to meet the mentioned criteria, the relevant sample included 20 public utility companies, i.e., comparable Decision Making Units (DMUs). However, their business is not limited to only one city, but may also cover a larger geographical area. Table 1 provides an overview of 20 public utility companies (DMUs) included in the research methodology and the corresponding Croatian cities and municipalities in which waste collection service is provided.

\begin{tabular}{|c|c|c|c|}
\hline $\mathrm{DMU}$ & $\begin{array}{c}\text { City; } \\
\text { Municipality }\end{array}$ & $\mathrm{DMU}$ & $\begin{array}{c}\text { City; } \\
\text { Municipality }\end{array}$ \\
\hline $\begin{array}{l}\text { FLORA VTC } \\
\text { D.O.O. }\end{array}$ & $\begin{array}{c}\text { Virovitica; } \\
\text { Suhopolje, } \\
\text { Gradina, Špišić } \\
\text { Bukovica, } \\
\text { Lukač } \\
\end{array}$ & PARK D.O.O. & Buzet; Lanišće \\
\hline $\begin{array}{c}\text { ČISTOĆA D.O.O. } \\
\text { KARLOVAC }\end{array}$ & $\begin{array}{l}\text { Karlovac; } \\
\text { Draganić }\end{array}$ & $\begin{array}{l}\text { GKP PRE-KOM } \\
\text { D.O.O. }\end{array}$ & $\begin{array}{c}\text { Prelog; } \\
\text { Goričan, Donji } \\
\text { Kraljevec, } \\
\text { Sveta Marija, } \\
\text { Donji Vidovec, } \\
\text { Donja } \\
\text { Dubrava, } \\
\text { Kotoriba }\end{array}$ \\
\hline $\begin{array}{l}\text { VG ČISTOĆA } \\
\text { D.O.O. }\end{array}$ & Velika Gorica & $\begin{array}{l}\text { KOMUNALNO- } \\
\text { ZABOK D.O.O. }\end{array}$ & $\begin{array}{c}\text { Zabok; Sveti } \\
\text { Križ Začretje, } \\
\text { Bedekovčina, } \\
\text { Veliko } \\
\text { Trgovišće, } \\
\text { Krapinske } \\
\text { Toplice } \\
\end{array}$ \\
\hline $\begin{array}{l}\text { KOMUNALAC } \\
\text { VRBOVEC } \\
\text { D.O.O. }\end{array}$ & $\begin{array}{l}\text { Vrbovec; } \\
\text { Preseka, } \\
\text { Dubrava, } \\
\text { Rakovec, } \\
\text { Gradec, } \\
\text { Farkaševac }\end{array}$ & $\begin{array}{c}\text { KOMUNALNO } \\
\text { ODRŽAVANJE } \\
\text { D.O.O. }\end{array}$ & Ploče; Gradac \\
\hline
\end{tabular}




\begin{tabular}{|c|c|c|c|}
\hline KOMBEL D.O.O. & Belišće & $\begin{array}{l}\text { BARANJSKA } \\
\text { ČISTOĆA D.O.O. }\end{array}$ & $\begin{array}{c}\text { Beli Manastir; } \\
\text { Čeminac, } \\
\text { Jagodnjak, } \\
\text { Popovac, } \\
\text { Kneževi } \\
\text { Vinogradi, } \\
\text { Petlovac, } \\
\text { Darda, Bilje, } \\
\text { Draž }\end{array}$ \\
\hline $\begin{array}{l}\text { KOMUNALAC } \\
\text { PETRINJA } \\
\text { D.O.O. }\end{array}$ & Petrinja & LUKOM - D.O.O. & Ludbreg \\
\hline $\begin{array}{l}\text { MAKARSKI } \\
\text { KOMUNALAC } \\
\text { D.O.O. }\end{array}$ & Makarska & $\begin{array}{c}\text { DUGOSELSKI } \\
\text { KOMUNALNI I } \\
\text { PODUZETNIČKI } \\
\text { CENTAR D.O.O. }\end{array}$ & Dugo Selo \\
\hline $\begin{array}{l}\text { KOMUNALNO } \\
\text { HVAR D.O.O. }\end{array}$ & Hvar & $\begin{array}{c}\text { ČISTOĆA I } \\
\text { ZELENILO D.O.O. }\end{array}$ & Knin; Ervenik \\
\hline $\begin{array}{c}\text { GOSPODARENJE } \\
\text { OTPADOM } \\
\text { SISAK D.O.O. } \\
\end{array}$ & $\begin{array}{c}\text { Sisak; Lekenik, } \\
\text { Martinska Ves, } \\
\text { Sunja } \\
\end{array}$ & $\begin{array}{c}\text { VRANJEVO } \\
\text { D.O.O. }\end{array}$ & Otok \\
\hline $\begin{array}{l}\text { SLATINA KOM } \\
\text { D.O.O. }\end{array}$ & $\begin{array}{c}\text { Slatina; Nova } \\
\text { Bukovica, } \\
\text { Čađavica, } \\
\text { Sopje, Mikleuš } \\
\end{array}$ & $\begin{array}{l}\text { INFRA-GRAD } \\
\text { D.O.O. }\end{array}$ & Obrovac \\
\hline
\end{tabular}

Source: Author's design

Table 1: Utility companies with the corresponding cities and municipalities in Croatia

In Table 1 it is evident that more than half of the utility companies (11) provide municipal services not only in their home cities, but in surrounding (neighbouring) municipalities as well. This is economically viable due to the economy of scale and the phenomenon of average costs reduction.

According to The Public Utilities Act [22], companies that provide municipal services in Croatia are obliged to ensure permanent and quality provision of municipal services, maintain utility facilities and equipment in good working order, perform municipal services in accordance with the principles of sustainable development and ensure the transparency of work. The Public Utilities Act in referring to municipal services defines the following activities: drinking water supply, drainage and wastewater treatment, public passenger transport, waste disposal, maintenance of public areas, management of green markets, maintenance of cemeteries and crematories and transport of the deceased, chimney sweeping and public lighting control. Importantly, companies analysed in this paper do not 
provide all of the mentioned services. However, all of the companies provide at least one basic municipal service, which is waste collection, removal and disposal, i.e., waste management. The Sustainable Waste Management Act [23] defines municipal waste as waste produced in households and waste found in nature with composition similar to household waste, except for industrial waste and the waste from agriculture and forestry activities. Furthermore, almost all of the utility companies in the research provide services such as maintenance of public areas, management and maintenance of cemeteries and crematories, as well as funeral services. The maintenance of public areas refers to the maintenance of public green spaces, sidewalks and pedestrian zones, open sewers, squares, parks, playgrounds, public traffic areas and parts of public roads passing through rural settlements, when not maintained as public roads under special law. The analysis excludes utility companies that perform certain additional tasks and activities, such as major construction work in civil engineering, natural gas supply, construction and maintenance of telecommunications infrastructure, port activities such as port management, etc. Although municipal services may vary depending on the decisions and needs of public authorities, we conclude that all utility companies in this study share the same characteristic in performing the primary function for which they were established, i.e., the collection and disposal of municipal waste. Considering the above mentioned, the same core service of municipal waste collection and disposal, and the fact that utility companies operate only in cities (including associated municipalities), with the exception of major cities in the Republic of Croatia, the conclusion is that the research sample satisfies conditions of the DEA methodology.

The following section will analyse previous studies that evaluate the relative efficiency of municipal waste collection.

\section{Previous research}

One of the first empirical studies on waste collection and associated costs was conducted in 1965, which analysed 25 small towns located in a certain geographical area in the USA [11]. In the following years, studies covered a larger sample of companies. For example, Stevens [19] analysed 340 public and private companies (in the period 1974-1975) which exclusively provided waste collection services in US cities (the companies serviced populations of 2,500 to 700,000 inhabitants). The research showed that household costs fell in all analysed market structures if the population was at least 20,000, and that the total average of household expenditure was lower when the utility company was a private monopolist, as opposed to a public monopolist. The authors Dubin and Navarro [9] conducted a study on a sample of 261 cities in the USA, and examined the organization of the markets in the context of household waste collection, with the associated disadvantages in the form of public goods. 
The previously mentioned studies were based on a parametric analysis, however non-parametric analysis methods have been used increasingly as of late. These methods do not require a knowledge of direct dependency between input and output. In other words, determining the (positive) relationship between input and output is not necessary, however it must be verified. One of the most frequently used non-parametric methods is Data Envelopment Analysis (DEA), which is used to determine and assess the relative efficiency of similar subjects or units (DMUs). DEA is a powerful service management and benchmarking technique. Numerous studies have used DEA methodology in theoretical development [16], and to measure the relative efficiency of different social activities and industries [7], such as the retailing sector, banking sector, energy sector [24], transport system, stock markets [10], the provision of public services such as education, health care, municipal services and other types of services, or to assessment the relative efficiency of national economies, i.e., countries and counties [20]. These were followed by a large number of studies that evaluated the relative efficiency of municipal services. Such studies usually analyse only a small number of variables in an empirical model, and the measurement of the relative efficiency is not comprehensive or incomplete. However, they also show the real state of the subject on the market compared to others in the same industry, and using projections the functioning of the observed units can be improved.

The study based on the DEA method was conducted in 46 of the largest USA cities in the period between 1993 and 1998, and evaluated the relative efficiency of 11 municipal services. The observed services included facility management, library services, road maintenance, emergency medical services, maintenance of parks and recreation areas, transportation, fire protection, police services, water supply, vehicle fleet management and solid waste collection. The variables used in the DEA model for solid waste collection included only two inputs (number of employees and the budget stipulated for the solid waste collection activity) and one output (number of residents covered by the activity). Although the overall relative efficiency was evaluated for all 46 cities (with Phoenix given the highest rating and Oakland the lowest rating for a city), due to scarce and inaccessible data, relative efficiency of solid waste collection was assessed for only 10 cities in the period from 1994 to 1998 (St. Louis being the highest and Fort Worth the lowest rated subject) [15]. Other information highlighted the differences in the relative efficiency between the selected cities, as well as differences in the efficiency of providing certain municipal services.

The relative efficiency of municipal solid waste collection was evaluated in Taiwan, and for that purpose aggregate indicators were devised. On the basis of five criteria used for selecting indices, applicability of various key indicators for relative efficiency was evaluated; the indicators (cost per unit of collected municipal solid waste, the amount of waste collected per unit of time, amount of 
waste collected per municipal vehicle, the population served by a waste collection service, amount of waste collected per vehicle miles travelled) were then included in the process of forming aggregate indicators. The relative efficiency of local municipal solid waste collection was analysed using the DEA method. Based on the results of the DEA method, a common set of weights was generated for five key indicators of efficiency. In the final step, the proposed aggregate indicator was used to evaluate the relative efficiency of municipal solid waste collection performed by 307 local municipal subjects in Taiwan [12].

With the aim of evaluating cost efficiency, a study was conducted in Italy in which 103 large Italian municipalities or cities were analysed in the 2011 fiscal year. In Data Envelopment Analysis the relative efficiency was evaluated using the CCR (cf. Pt. 4.1.) and BCC (cf. Pt. 4.2.) models by applying the inputoriented model, the returns to scale were explored. The results suggested that $58 \%$ and $64 \%$ of the units in the sample were CCR efficient and BCC efficient, respectively, while the average efficiency scores for CCR and BCC were 0.85 and 0.88 , respectively. Furthermore, the results determined inefficiency by volume in 43 DMUs, i.e., municipalities, all of which points to the conclusion that public spending by municipalities is generally inefficient [14].

In Japanese prefectures, the production efficiency of public and private municipal logistics for solid waste, including household and industrial solid waste was estimated. Whether through public activities or outsourcing to private operators, the prefectures of public authorities in Japan have direct governance over waste collection and treatment. Using the DEA method and several other models, production efficiency was estimated based on multiple inputs (number of trucks and workers in public and private sectors) as well as multiple outputs (solid waste (measured in tonnes) from households and industry collected by private and public operators) in 47 Japanese prefectures. The results consistently showed that geographical features, such as the number of remote inhabited islands, are a dominant factor in determining relative inefficiency. Moreover, the results suggest that the prefectures with higher engagement by the private sector have a higher relative efficiency, measured in terms of household solid waste collection, while a higher proportion of private work affects relative efficiency negatively [13].

In applying the DEA method and non-controllable input [21], the technical and cost relative efficiency of waste collection was analysed in 73 municipalities in the Spanish province of Catalonia in 1998. The observed inputs included the capacity of containers in liters (number of containers of capacity X) and the capacity of fleets in liters (number of vehicles of capacity X) as capital factors, and the number of annual hours worked by drivers and waste loaders as work factors. Outputs refer to annual tonnes of collected organic waste (quantitative indicator) and waste collection frequency per week (quality indicator). In evaluating cost efficiency, physical inputs are substituted with the total annual cost of waste collection, while retaining the same outputs. The uncontrollable variable (in both 
cases involving efficiency measurement) is the number of kilometres travelled by a vehicle from a collection point to a landfill, and seasonal population due to the large number of tourists in some municipalities, who generated more waste. The research results support the thesis that uncontrollable variables do not significantly affect the smooth provision of service, with the exception of several municipalities [3].

Following the literature review, in which the relative efficiency of waste collection in different countries was evaluated, and upon describing various models and variables, the subsequent section evaluates the relative cost efficiency of selected Croatian municipal service providers that collect and manage waste.

\section{Research methodology}

\subsection{Introduction to DEA}

Data envelopment analysis is one of the methodologies that is widely used to calculate efficiency and effectiveness of numerous DMUs operating in similar conditions. It is a type of non-parametric, comparative, performance analysis, which assumes that there are $n$ DMUs to evaluate where not all DMUs are efficient. These DMUs convert multiple inputs into multiple outputs and therefore devising a functional form, relationship between them is not possible (or is unknown to us), but requires verification of the positive correlation between inputs and outputs. DEA is based on mathematical programming and evaluates the efficiency of a DMU relative to a set of comparable DMUs. DEA forms an efficient frontier using efficient units as a standard of best-achieved performance. DMUs that are not relatively efficient are below the efficiency frontier, and DEA then measures the amount of inefficiency (distance from efficiency frontier) of inefficient units whilst making comparisons with the best practice units. For example, if the relative efficiency of DMU equals 0.58 , it means that the DMU is relatively inefficient compared to the best units, and can be qualified as an efficiency rating of $58 \%$. DEA also provides a way for inefficient DMUs to achieve an efficient frontier due to projections such as potential changes of inputs or outputs. If senior management want to determine the maximum possible values of outputs, using the same values of inputs, the output-oriented DEA model is the most appropriate. Otherwise, if senior management is interested in the minimum possible values of inputs used for the same level of outputs, an input-oriented DEA model is the best choice. Furthermore, the relatively efficient of DMUs is an element of a subgroup that DEA denotes as a reference set. These units are those that are efficient, compared to other units, and are the best practice models, though they could be somewhat inefficient. Therefore, it is not about absolute efficiency but rather relative efficiency. The methodology still remains valuable, especially in complex situations where numerous units are operating with multiple 
outputs and inputs and which cannot be analysed using other techniques that may be too complicated for management purposes.

According to the above, we conclude that DEA is powerful benchmarking technique that help managers to [17], [18]:

1) assess their organization`s relative performance

2) identify top performance

3) identify ways of improving performance

4) achieve potential savings

5) improve the productivity

6) reduce operating costs

7) increase profitability

8) monitor the efficiency changes over time

9) set targets.

That is why "...researchers in a number of fields have quickly recognized that it is an excellent and easily used methodology for modelling operational processes for performance evaluations." [7]. Like every other methodology, DEA has its strengths and limitations as a static methodology but has been proven to extremely valuable and is applied in many situations, such as assessing the relative efficiency of countries, banks, hotels, education, management, health care, airports, shops, sport and so on.

\subsection{CCR model}

One of the basic DEA models is the Charnes-Cooper-Rhodes model (CCR model) based on the constant returns to scale assumption and efficiency defined as the ratio of output to input, where more output per unit of input reflects greater efficiency. Suppose there are $n$ DMUs converting $m$ inputs $\left(x_{i}, i=1,2, \ldots, m\right)$ into $s$ outputs $\left(y_{r}, r=1,2, \ldots, s\right)$. The idea behind the CCR model is to form a virtual input $\left(v_{1} x_{1 o}+\ldots+v_{m} x_{m o}\right)$ and virtual output $\left(u_{1} y_{1 o}+\ldots+u_{s} y_{s o}\right)$ for each $\mathrm{DMU}_{j}$ included the analysis, using output weights $\left(u_{r}\right)(r=1, \ldots, s)$ and input weights ( $\left.v_{i}\right)(i=1, \ldots, m)$ and then solve it by adhering to the fractional programming problem [5].

\section{Model 1}

$$
\max _{v, u} \theta=\frac{u_{1} y_{1 o}+u_{2} y_{2 o}+\ldots+u_{s} y_{s o}}{v_{1} x_{1 o}+v_{2} x_{2 o}+\ldots v_{m} x_{m o}}
$$


subject to:

$$
\begin{array}{r}
\frac{u_{1} y_{1 j}+\ldots+u_{s} y_{s j}}{v_{1} x_{1 j}+\ldots v_{m} x_{m j}} \leq 1 \quad(\mathrm{j}=1, \ldots, n) \\
v_{1}, v_{2}, \ldots, v_{m} \geq 0 \\
u_{1}, u_{2}, \ldots, u_{s} \geq 0
\end{array}
$$

The optimal values for weights $\left(u_{r}\right)(r=1, \ldots, s)$ and $\left(v_{i}\right)(i=1, \ldots, m)$ will be obtained from CCR model for every DMU and they are determined from the output and input data of all DMUs in the peer group of data. The constraints (2) mean that the maximum value of the goal function $\theta$ is equal to or less than 1 , or that the maximum efficiency result of a DMU under the consideration is $100 \%$. This model can be rewritten as [17]:

\section{Model 2}

$$
\max \quad \theta=\sum_{r=1}^{s} u_{r} y_{r o}
$$

subject to:

$$
\begin{gathered}
\sum_{r=1}^{s} u_{r} y_{r j} \leq \sum_{i=1}^{m} v_{i} x_{i j} \quad(j=1, \ldots, n) \\
\sum_{i=1}^{m} v_{i} x_{i o}=1 \\
v_{1}, v_{2}, \ldots, v_{m} \geq 0 \\
u_{1}, u_{2}, \ldots, u_{s} \geq 0
\end{gathered}
$$

and finally as following dual linear programming formulation that seeks efficiency by minimizing (dual) efficiency of a DMU under consideration subject to two sets of inequality. 


\section{Model 3}

subject to:

$$
\operatorname{Min} \theta
$$

$$
\begin{gathered}
\sum \lambda_{j} x_{i j} \leq \theta x_{i o} \quad(i=1, \ldots, m) \\
\sum \lambda_{j} y_{r j} \geq y_{r o} \quad(r=1, \ldots, s) \\
\lambda_{j} \geq 0 \quad(j=1, \ldots, n)
\end{gathered}
$$

Model 3 enables the determining of the weights of benchmarks $\lambda$. If a DMU is efficient, then the $\lambda$ values are equal to 1 . Otherwise, for those DMUs that are inefficient, the $\lambda$ values will be expressed in their efficiency reference set. The following model 4 enables optimizes slack values to achieve the efficiency frontier:

\section{Model 4}

$$
\begin{gathered}
\operatorname{Max} \quad \sum_{i=1}^{m} s_{i}^{-}+\sum_{r=1}^{s} s_{r}^{+} \\
\sum_{j=1}^{n} \lambda_{j} x_{i j}+s_{i}^{-}=\theta^{*} x_{i o} \quad(i=1, \ldots, m) \\
\sum_{j=1}^{n} \lambda_{j} y_{r j}-s_{r}^{*}=y_{r o} \quad(r=1, \ldots, s) \\
\lambda_{j} \geq 0 \quad(j=1, \ldots, n)
\end{gathered}
$$

Model 5 presents an input-oriented CCR model that obtains optimal slack values in order to achieve the efficiency frontier.

\section{Model 5}

$$
\begin{gathered}
\text { Min } \quad \theta-\varepsilon\left(\sum_{i=1}^{m} s_{i}^{-}+\sum_{r=1}^{s} s_{r}^{+}\right) \\
\sum_{j=1}^{n} \lambda_{j} x_{i j}+s_{i}^{-}=\theta x_{i o} \quad(i=1, \ldots, m)
\end{gathered}
$$




$$
\begin{array}{cc}
\sum_{j=1}^{n} \lambda_{j} y_{r j}-s_{r}^{+}=y_{r o} & (r=1, \ldots, s) \\
\lambda_{j} \geq 0 & (j=1, \ldots, n)
\end{array}
$$

The $\varepsilon$ in the objective function is non-Archimedean and is infinitely small, or less than any real positive number. If an optimal solution $\left(\theta^{*}, \lambda^{*}, s^{-^{*}}, s^{+^{*}}\right)$ satisfies $\theta^{*}=1, \lambda=1$, input slacks $s^{-^{*}}=0$, and output slacks $s^{+^{*}}=0$, then DMUo (DMU under consideration) is relatively efficient [5] and lies on the efficient frontier. Otherwise, it is relatively inefficient and lies below the efficient frontier. Input-oriented model 5 optimizes slack values to achieve the efficiency frontier, and the so-called projections (target values) on the efficient frontier that can be calculated as

Inputs:

$$
\widehat{x}_{i o}=\theta^{*} x_{i o}-s_{i}^{-*} \quad(i=1 .,, . . m)
$$

Outputs:

$$
\hat{y}_{r o}=y_{r o}+s_{i}^{+*} \quad(r=1, \ldots, s)
$$

\subsection{Input-oriented CCR model with non-controllable and controllable inputs}

The input-oriented CCR model with non-controllable and controllable inputs (Model 6) is an extension to the basic CCR envelopment model (Model 5). Namely, sometimes DMUs have inputs or outputs that are classified as controllable, given that the DMU can exert an influence on them, but there are usually inputs or outputs on which the DMU does not have influence at all. Those variables should be included in the DEA model because they have an influence on the efficiency score and projection values [3]. This means that non-controllable inputs will be considered given and will not be changed. Only values of controllable inputs for inefficient DMUs will be changed because the DMU is able to control them [17].

\section{Model 6}

$$
\text { Min } \theta-\varepsilon\left(\sum_{i=1}^{m} s_{i}^{-}+\sum_{r=1}^{s} s_{r}^{+}\right)
$$




$$
\sum_{j=1}^{n} \lambda_{j} x_{i j}+s_{i}^{-}=\theta x_{i o} \quad(i \in I)
$$

where I represents controllable inputs

$$
\sum_{j=1}^{n} \lambda_{j} x_{i j}+s_{i}^{-}=x_{i o} \quad(i \notin I)
$$

where I represents non-controllable inputs

$$
\begin{array}{cc}
\sum_{j=1}^{n} \lambda_{j} y_{r j}-s_{r}^{+}=y_{r o} & (r=1, \ldots, s) \\
\lambda_{j} \geq 0 & (j=1, \ldots, n)
\end{array}
$$

To calculate the projections for all inefficient DMUs, we use following expressions $[17]$ :

Inputs:

$$
\begin{array}{ll}
\hat{x}_{i o}=\theta^{*} x_{i o}-s_{i}^{-*} & (i \in I), \text { where I represents controllable inputs } \\
\hat{x}_{r o}=x_{i o}-s_{i}^{-*} & (i \notin I), \text { where I represents non-controllable inputs }
\end{array}
$$

Outputs:

$$
\widehat{y}_{r o}=y_{r o}+s_{i}^{+*} \quad(r=1, \ldots, s)
$$

\subsection{BCC model}

The Banker-Charnes-Cooper model (BCC model) is another commonly used DEA model based on the assumption of variable returns to scale with piecewise linear efficiency frontier [2]. It differs from the CCR model (Model 5) only in that it includes convexity constraints:

$$
\sum_{j=1}^{n} \lambda_{j}=1, \lambda_{j} \geq 0 \quad \forall j
$$

Model 7 represents an input-oriented BCC model that obtains optimal slack values in order to achieve the piecewise linear efficiency frontier. Due to different efficiency frontiers, and compared to the CCR model, BCC efficiency scores for 
all DMUs under evaluation are better or at least the same as CCR efficiency scores. That is why it is very important to take into account the type of returns to scale before evaluating DMUs.

\section{Model 7}

$$
\begin{gathered}
\text { Min } \theta-\varepsilon\left(\sum_{i=1}^{m} s_{i}^{-}+\sum_{r=1}^{s} s_{r}^{+}\right) \\
\sum_{j=1}^{n} \lambda_{j} x_{i j}+s_{i}^{-}=\theta x_{i o} \quad(i=1, \ldots, m) \\
\sum_{j=1}^{n} \lambda_{j} y_{r j}-s_{r}^{+}=y_{r o} \quad(r=1, \ldots, s) \\
\sum_{j=1}^{n} \lambda_{j}=1 \\
\lambda_{j} \geq 0 \quad(j=1, \ldots, n)
\end{gathered}
$$

The definition for BCC efficiency [5] says that if the optimal solution of the BCC model $\left(\theta_{B}^{*}, \lambda^{*}, s^{-^{*}}, s^{+^{*}}\right)$ satisfies $\theta_{B}^{*}=1$ and $s^{-^{*}}=0, s^{+^{*}}=0$, the $\mathrm{DMU}_{\mathrm{o}}$ is BCC efficient and lies on the efficient frontier, otherwise the BCC inefficient and lies below the efficient frontier. As in the case of the CCR model, the projections for all inefficient DMUs can be calculated as follows

Inputs:

$$
\widehat{x}_{i o}=\theta^{*} x_{i o}-s_{i}^{-*} \quad(i=1 .,, ., m)
$$

Outputs:

$$
\hat{y}_{r o}=y_{r o}+s_{i}^{+*} \quad(r=1, \ldots, s)
$$




\subsection{Input-oriented BCC model with non-controllable and controllable inputs}

The input-oriented BCC model with non-controllable and controllable inputs (Model 8) is an extension to the basic BCC envelopment model (Model 7).

\section{Model 8}

$$
\begin{array}{r}
\operatorname{Min} \theta-\varepsilon\left(\sum_{i=1}^{m} s_{i}^{-}+\sum_{r=1}^{s} s_{r}^{+}\right) \\
\sum_{j=1}^{n} \lambda_{j} x_{i j}+s_{i}^{-}=\theta \quad x_{i o} \quad(i \in I)
\end{array}
$$

where I represents controllable inputs

$$
\sum_{j=1}^{n} \lambda_{j} x_{i j}+s_{i}^{-}=x_{i o} \quad(i \notin I)
$$

where I represents non-controllable inputs

$$
\begin{gathered}
\sum_{j=1}^{n} \lambda_{j} y_{r j}-s_{r}^{+}=y_{r o} \quad(r=1, \ldots, s) \\
\sum_{j=1}^{n} \lambda_{j}=1 \\
\lambda_{j} \geq 0 \quad(j=1, \ldots, n)
\end{gathered}
$$

To calculate the projections for all inefficient DMUs, we use following expressions [17]:

Inputs:

$$
\begin{aligned}
& \hat{x}_{i o}=\theta^{*} x_{i o}-s_{i}^{-*} \quad(i \in I), \text { where I represents controllable inputs } \\
& \hat{x}_{r o}=x_{i o}-s_{i}^{-*} \quad(i \notin I), \text { where I represents non-controllable inputs }
\end{aligned}
$$

Outputs:

$$
\hat{y}_{r o}=y_{r o}+s_{i}^{+*} \quad(r=1, \ldots, s)
$$




\section{Application of Data Envelopment Analysis}

The relative efficiency of 20 utility companies in the Republic of Croatia was performed for 2014 using the Data Envelopment Analysis method and the software package DEA-Solver Professional Release 11.0. The observed utility companies (DMUs) were included in the research due to the availability of data, the size of the company, the size of the city in which the company delivers the service, and the variety of municipal services. Input and output variables were taken from the Amadeus database [4] and the Croatian Bureau of Statistics [8]. The following section provides an overview of the selection of adequate inputs and outputs and examines their correlation. DEA does not require any functional form for converting inputs to outputs, but presumes that an increase in input leads to an increase in output. The appropriate type of model is chosen based on the envelope, i.e., the constant or variable returns to scale, and the orientation towards input or output.

\subsection{Selection of inputs and outputs}

Another advantage of the DEA method over traditional non-parametric methods is the use of multiple inputs and outputs which can be expressed in different measurement units. Inputs present the resources used, while outputs present the results achieved, and their selection reflects the interest of analysts in using the DEA method. In this paper, the relative efficiency of utility companies is primarily evaluated through monetary units, thus in fact representing the cost efficiency. In addition to the monetary value, the analysis included the physical value as well.

Inputs:

1. total assets refers to the total amount of assets owned by a company, consisting of fixed assets and current assets (expressed in euros);

2. material cost is the cost of materials or resources invested in the production process (expressed in euros);

3. cost of employees is the cost of labor in the production process (expressed in euros);

4. population size is the number of people to whom the utility company delivers its services

Output:

1. earnings before interest, taxes, depreciation and amortization (EBITDA) is an indicator of the company's financial results and represents a "pure" profit/loss of the company (expressed in euros). 
The selection of the input total assets as a relevant economic value, represents an indispensable variable in evaluating the relative efficiency of companies, since assets include all the resources at a company's disposal in order to achieve future economic benefits. The total assets value depends on the size of the company, its organizational structure and the organization of its production, technical and technological development of the company, activities that the company offers, other participants on the market, as well as other factors. On the other hand, material costs and cost of employees reduce the company's economic benefit or profit. They are determined by the its business operations, and in municipal activities, both types of costs are high. In the model, these inputs are classified as controllable, as the company can influence them - they can be changed or adapted to the company's needs. The last input, population size, is a non-controllable variable. This means that at the projections on the efficient frontier, this variable is considered given and will not change. Proper evaluation of the relative efficiency of utility companies, or the companies that collect waste, requires careful consideration not only of the inputs directly controlled by the company and its management, but also consideration of certain factors, the values of which cannot be changed by company management. These factors can significantly influence and change the results of the relative efficiency [3]. For that reason, a noncontrollable input is introduced in the study, referring to the number of inhabitants to whom each utility company delivers its services in a specific area. The population figures are taken from the Croatian Bureau of Statistics (for 2011), and refer to the inhabitants of certain cities and surrounding municipalities in which a utility company provides one of its basic waste collection activities.

The variable earnings before interest, taxes, depreciation and amortization is used as the only output in the model. This variable directly shows the success of the company, and its financial results in the observed 2014 year. In addition to the analysis of profitability, EBITDA can be used for evaluating the company's relative efficiency, since it eliminates the effects of financing decisions, the statutory tax rates and the application of various accounting policies. In taking into account only one (mentioned) quantitative variable, assessing the relative efficiency is not possible due to the lack of other qualitative variables and/or other quantitative variables on the output side. The limitations of the analysis are thus recognized in the research, since the focus was on evaluating the cost efficiency. Table 2 below shows the statistics of the observed inputs and output used in the DEA model. 


\begin{tabular}{|l|c|c|c|c|c|}
\hline & $\begin{array}{c}\text { Total } \\
\text { assets }\end{array}$ & $\begin{array}{c}\text { Material } \\
\text { cost }\end{array}$ & $\begin{array}{c}\text { Cost of } \\
\text { employees }\end{array}$ & $\begin{array}{c}\text { Population } \\
\text { size }\end{array}$ & EBITDA \\
\hline Max & $6,739,750$ & $3,883,376$ & $1,668,834$ & 63,517 & 747,877 \\
\hline Min & 201,672 & 69,339 & 137,742 & 4,251 & 0 \\
\hline Average & $2,320,395$ & 563,734 & 731,767 & 24,897 & 252,486 \\
\hline SD & $1,763,841$ & 792,175 & 471,576 & 18,685 & 213,128 \\
\hline
\end{tabular}

Source: Author's calculation

Table 2: Statistics of inputs and output in the DEA model for 2014

The minimum zero value of the variable EBITDA should be noted, due to the fact that a certain company sustained operating losses in 2014, and as such, evaluating its relative efficiency is inappropriate. Evaluation of a company's relative efficiency as non-negative values is an important precondition for the Data Envelopment Analysis method. In choosing the appropriate inputs and outputs, assuming their positive correlation is necessary, as shown in Table 3 below.

\begin{tabular}{|l|c|c|c|c|c|}
\hline Inputs/Output & $\begin{array}{c}\text { Total } \\
\text { assets }\end{array}$ & $\begin{array}{c}\text { Material } \\
\text { cost }\end{array}$ & $\begin{array}{c}\text { Cost of } \\
\text { employees }\end{array}$ & $\begin{array}{c}\text { Population } \\
\text { size }\end{array}$ & EBITDA \\
\hline Total assets & 1 & 0.2356850 & 0.6429895 & 0.3490618 & 0.7985559 \\
\hline Material cost & 0.2356850 & 1 & 0.5054597 & 0.2942075 & 0.2005626 \\
\hline $\begin{array}{l}\text { Cost of } \\
\text { employees }\end{array}$ & 0.6429895 & 0.5054597 & 1 & 0.6810816 & 0.6541182 \\
\hline Population size & 0.3490618 & 0.2942075 & 0.6810816 & 1 & 0.4836435 \\
\hline EBITDA & 0.7985559 & 0.2005626 & 0.6541182 & 0.4836435 & 1 \\
\hline
\end{tabular}

Source: Author's calculation

Table 3: Inputs and output correlation coefficients in 2014

It is evident in the table that all inputs and outputs have a positive correlation coefficient. The coefficient is highest between the input total assets and the output earnings before interest, taxes, depreciation and amortization, which represents a high correlation between the variables, i.e., an increase in assets boosts a company's profits. After selecting input and output variables and determining positive correlation coefficients, a DEA model must be selected based on the returns to scale, i.e., the envelope. 


\subsection{Selecting the model based on the envelope}

In this paper, the input population size has already been introduced, cannot be changed or influenced, and is therefore considered non-controllable input. Other inputs, total assets, material cost and cost of employees, are controllable, and the output earnings before interest, taxes, depreciation and amortization is also controllable. Thus, the measurement and evaluation of the relative efficiency is carried out using an alternative, non-controllable DEA model.

The non-controllable model is used to evaluate the relative efficiency in terms of constant returns to scale (CRS) and variable returns to scale (VRS). Considering that it is impossible to predict the performance of the observed utility companies concerning the returns to scale, the relative efficiency is assessed using the constant (Model 6) and variable (Model 8) returns to scale, as is shown in Table 4.

\begin{tabular}{|l|c|c|}
\hline Results of the relative efficiency & CCR model (CRS) & BCC model (VRS) \\
\hline No. of efficient DMUs & 5 & 8 \\
\hline No. of inefficient DMUs & 15 & 12 \\
\hline Average result of the efficiency & 0.6463 & 0.7302 \\
\hline Max. result of the efficiency & 1 & 1 \\
\hline Min. result of the efficiency & 0.2576 & 0.3042 \\
\hline
\end{tabular}

Source: Author's calculation

Table 4: Relative efficiency with the use of constant and variable returns to scale

Table 4 shows the results of the relative efficiency of 20 DMUs or utility companies evaluated in the CCR model and constant returns to scale, and the BCC model and variable returns to scale. There is a substantial difference in the number of efficient companies assessed using the respective returns to scale, i.e., there are $60 \%$ more efficient companies in the BCC model than in the CCR model. This implies the operation of the company under variable returns to scale. An additional argument for the use of variable returns to scale is the view that it is possible to displace (translate) data without changing the frontiers of efficiency in the model with variable returns, and in that case, the classification of DMUs as efficient and inefficient (by displacing the data) is consistent or translation invariant [1].

\subsection{Model selection considering the orientation}

As the relative efficiency can be assessed under constant and variable returns to scale, the non-controllable model can be input or output oriented. The inputoriented model aims at reducing input amounts to the efficiency frontier while 
keeping the outputs constant, while the output-oriented model maximizes output levels within existing input capacities. Given that this work is aimed at reducing company costs, the input-oriented model was selected. Moreover, input-oriented model (variable returns to scale) is selected since translation invariance with respect to outputs can be applied, but not the inputs [6]. This means that the negative output values can be transformed into positive or non-negative values. Namely, one of the companies had a negative output value of earnings before interest, taxes, depreciation and amortization in 2014, which transformed into a zero value. Due to the translation invariance, the efficiency frontier remains unchanged despite a change in output values. In the next chapter, the results of the relative efficiency for municipal service providers in the Republic of Croatia are presented.

\section{Empirical results}

This chapter presents the results for the relative efficiency of 20 selected utility companies in Croatia based on data from 2014 and applying the Data Envelopment Analysis method and non-controllable input-oriented model with variable returns to scale (Model 8). In addition to the results for relative efficiency of the companies, the projection values for controllable inputs (46) are identified for several relatively inefficient utility companies with the aim of achieving relative efficiency. Below, Table 5 displays the results of the relative efficiency.

\begin{tabular}{|c|c|c|}
\hline Rank & DMU & Result \\
\hline 1 & BARANJSKA ČISTOĆA D.O.O. & 1 \\
\hline 1 & GOSPODARENJE OTPADOM SISAK D.O.O. & 1 \\
\hline 1 & INFRA-GRAD D.O.O. & 1 \\
\hline 1 & KOMUNALNO HVAR D.O.O. & 1 \\
\hline 1 & KOMUNALNO ODRŽAVANJE D.O.O. & 1 \\
\hline 1 & KOMUNALNO-ZABOK D.O.O. & 1 \\
\hline 1 & VG ČISTOĆA D.O.O. & 1 \\
\hline 1 & VRANJEVO D.O.O. & 1 \\
\hline 9 & ČISTOĆA I ZELENILO D.O.O. & 0.9576 \\
\hline 10 & DUGOSELSKI KOMUNALNI I PODUZETICKI & 0.8145 \\
\hline 11 & CENTAR D.O.O. & 0.7665 \\
\hline 12 & ČISTOĆA D.O.O. KARLOVAC & 0.6624 \\
\hline 13 & GKP PRE-KOM D.O.O. & 0.6221 \\
\hline 14 & KOMBEL D.O.O. & 0.5327 \\
\hline 15 & LUKOM - D.O.O. & 0.4189 \\
\hline
\end{tabular}




\begin{tabular}{|l|c|c|}
\hline 16 & KOMUNALAC VRBOVEC, D.O.O. & 0.4076 \\
\hline 17 & FLORA VTC D.O.O. & 0.4074 \\
\hline 18 & SLATINA KOM D.O.O. & 0.3904 \\
\hline 19 & KOMUNALAC PETRINJA D.O.O. & 0.3204 \\
\hline 20 & MAKARSKI KOMUNALAC D.O.O. & 0.3042 \\
\hline
\end{tabular}

Source: Author's calculation

Table 5: Relative efficiency of 20 utility companies (DMUs) in 2014

As has already been mentioned, in applying the variable returns to scale, 8 utility companies (DMUs) are assessed as relatively efficient and possess the highest efficiency score $\left(\theta^{*}=1\right)$, while 12 utility companies are assessed as relatively inefficient $\left(\theta^{*}<1\right)$. This is shown in Table 5 . What is noticeable is that the relative efficiency/inefficiency of a company is not tied to a particular geographical area in which it operates or from its secondary or additional activities, and there is no specific feature that suggests specific results.

Not only does evaluation of the relative efficiency using the Data Analysis Envelopment method provide an assessment of the current level of relative efficiency, or a comparison of the relatively inefficient of subjects with respect to the best companies, i.e., those with the highest level of efficiency, but what is especially important, it also provides information on how to eliminate inefficiency by identifying the sources and levels of relative inefficiency. This is ensured through projections on the efficiency frontier for each relatively inefficient utility company in order to become relatively efficient. Table 6 displays the projections on the efficiency frontier, i.e., the suggested reductions of input values in order to ensure efficiency.

\begin{tabular}{|c|c|c|c|c|}
\hline DMU & Result & $\begin{array}{l}\text { Change } \\
(\%) \text { of the } \\
\text { input total } \\
\text { assets }\end{array}$ & $\begin{array}{l}\text { Change }(\%) \\
\text { of the input } \\
\text { material } \\
\text { cost }\end{array}$ & $\begin{array}{l}\text { Change } \\
(\%) \text { of the } \\
\text { input cost } \\
\text { of } \\
\text { employees }\end{array}$ \\
\hline ČISTOĆA I ZELENILO & 0.9576 & $-4.24 \%$ & $-4.24 \%$ & $-4.24 \%$ \\
\hline $\begin{array}{l}\text { DUGOSELSKI } \\
\text { KOMUNALNI I } \\
\text { PODUZETNIČKI } \\
\text { CENTAR }\end{array}$ & 0.8145 & $-18.55 \%$ & $-56.44 \%$ & $-18.55 \%$ \\
\hline ČISTOĆA KARLOVAC & 0.7665 & $-23.35 \%$ & $-42.80 \%$ & $-24.37 \%$ \\
\hline GKP PRE-KOM & 0.6624 & $-33.76 \%$ & $-66.77 \%$ & $-33.76 \%$ \\
\hline KOMBEL & 0.6221 & $-38.00 \%$ & $-63.19 \%$ & $-37.79 \%$ \\
\hline LUKOM & 0.5327 & $-70.99 \%$ & $-58.79 \%$ & $-46.73 \%$ \\
\hline PARK & 0.4189 & $-68.01 \%$ & $-73.28 \%$ & $-58.11 \%$ \\
\hline
\end{tabular}




\begin{tabular}{|l|c|c|c|c|}
\hline $\begin{array}{l}\text { KOMUNALAC } \\
\text { VRBOVEC }\end{array}$ & 0.4076 & $-69.94 \%$ & $-65.04 \%$ & $-59.24 \%$ \\
\hline FLORA VTC & 0.4074 & $-62.93 \%$ & $-93.28 \%$ & $-59.26 \%$ \\
\hline SLATINA KOM & 0.3904 & $-60.96 \%$ & $-60.96 \%$ & $-60.96 \%$ \\
\hline $\begin{array}{l}\text { KOMUNALAC } \\
\text { PETRINJA }\end{array}$ & 0.3204 & $-67.96 \%$ & $-78.02 \%$ & $-67.96 \%$ \\
\hline $\begin{array}{l}\text { MAKARSKI } \\
\text { KOMUNALAC }\end{array}$ & 0.3042 & $-69.58 \%$ & $-80.44 \%$ & $-69.58 \%$ \\
\hline
\end{tabular}

Source: Author's calculation

Table 6: The projection of relatively inefficient utility companies in 2014

Table 6 gives an overview of all the observed relatively inefficient $\left(\theta^{*}<1\right)$ utility companies in the Republic of Croatia, together with the results of relative efficiency and the necessary changes (in percentages) of certain variables for the purpose of achieving relative efficiency $\left(\theta^{*}=1\right)$. Given that the input-oriented model is applied, relative efficiency is achieved by reducing input values while maintaining current outputs. The input population size, as an uncontrollable variable, is an exception and the company cannot influence a change or reduction of this input. Therefore, to become relatively efficient, the best rated relatively inefficient utility company Čistoća i zelenilo d.o.o. should reduce all input amounts, that is, its total assets, material costs and employee costs, each by $4.24 \%$. For the lowest rated utility company, Makarski komunalac d.o.o., to achieve relative efficiency, material costs should be reduced by $80.44 \%$, and total assets and employee costs by $69.58 \%$. Table 6 also shows other amounts of relative inefficiency of Croatian utility companies which were assessed as relatively inefficient.

Although the sources and the amounts of relative inefficiency of the utility companies do not show any regularities, the material costs of the companies evidently need to be drastically cut, i.e., each relatively inefficient utility company (with the exception of two companies) by more than $50 \%$. This shows that, to achieve relative efficiency, the utility companies must mainly focus on efficient management of material costs in business operations. Considering that employees costs are an input for the model, half of the relatively inefficient utility companies should reduce that particular cost by no more than $50 \%$ (from $4.24 \%$ to $46.73 \%$ ), while the other half of the relatively inefficient companies should correct (reduce) employee costs anywhere from $58.11 \%$ to $69.58 \%$. Furthermore, a few (5) of the relatively inefficient companies should reduce the input total assets by a relatively small amount (up to $38 \%$ ), whereas the remaining 7 companies should reduce total assets from $60.96 \%$ to $70.99 \%$. Taking into account all of the above, the analysis shows the significant overcapacity of relatively inefficient utility companies, suggesting to management that appropriate measures should be taken in order to achieve higher business efficiency. 


\section{Conclusion}

Municipal services such as the collection, removal and disposal of waste, represent one of the necessary activities carried out by public authorities in order to fulfil general social needs. The efficient management and spending of public resources affects the welfare of communities, especially users of the respective services. It is therefore vital to optimize these public activities. This paper analyses the communal activity of waste collection, which is provided regardless of the size of the city or municipality, or the level of development of an area. To assess the relative cost efficiency, this paper analysed 20 public utility companies that collect household waste in various cities and neighbouring municipalities in the Republic of Croatia based on data from 2014.

In the research, the Data Envelopment Analysis method was used, which, unlike parametric methods, does not presume any functional form linking inputs and outputs, and is a significant advantage in line with the application of noncontrollable input-oriented model with variable returns to scale. Population size is an uncontrollable variable, which cannot be influenced by a company, while controllable inputs include total assets, material cost and the cost of employees. The output is earnings before interest, taxes, amortization and depreciation. In the research, 8 utility companies in Croatia were assessed as relatively efficient, while 12 companies were assessed as relatively inefficient. In addition to the relative efficiency results for each utility company and the sources and amounts of relative inefficiency, this paper presents potential improvements for relatively inefficient companies, which is valuable information for management when making decisions to increase business efficiency.

Although municipal services vary, it should be noted that this paper compared only those utility companies that operate under similar conditions. Even if certain companies offer a larger number of municipal services, the impact of such activities on the results is not noticeable, nor does the application of Data Envelopment Analysis show that such companies are relatively more efficient or inefficient compared to other companies that provide only waste collection services.

To the knowledge of the authors of this paper, similar research in the Republic of Croatia that covers municipal service providers has not been conducted, hence the results represent a contribution to economic literature. This selected approach to research is evident in the conducted static analysis, therefore the suggestion is that future studies should include information on the operations of utility companies for a longer period of time and apply the window analysis method, which would allow access to relative efficiency results over time. 


\section{References}

[1] Ali, A. I. and Seiford, L. M. (1990). Translation invariance in data envelopment analysis. Operations Research Letters, 9(6), 403-405.

[2] Banker, R. D., Charnes, A. and Cooper, W. W. (1984). The Use of Categorical Variables in Dana Envelopment Analysis. Management Science, 30, 10781092.

[3] Bosch, N., Pedraja, F. and Suárez-Pandiello, J. (2001). The efficiency of refuse collection services in Spanish municipalities: Do non-controllable variables matter? Institut d'Economia de Barcelona. Working Paper No. 4.

[4] Bureau van Dijk. Amadeus database. Available at: https://amadeus.bvdinfo .com [Accessed 7/03/16].

[5] Cooper, W. W., Seiford, L. M. and Tone K. (2006). Introduction to Data Envelopment Analysis and Its Uses. New York: Springer.

[6] Cooper, W. W., Seiford, L. M. and Tone, K. (2000). Data Envelopment Analysis - A Comprehensive Text with Models, Applications, References and DEA-Solver Software. Boston: Kluwer Academic Publishers.

[7] Cooper, W. W., Seiford L. M. and Zhu J. (2004). Handbook on Data Envelopment Analysis. Boston: Kluwer Academic Publishers.

[8] Croatian Bureau of Statistics. (2011). The contingents of the population in the cities/municipalities. Review 2011. Available at: http://www.dzs.hr/ Hrv/censuses/census2011/results/htm/H01_01_03/H01_01_03.html [Accessed 8/03/16].

[9] Dubin, J. A. and Navarro, P. (1988). How markets for impure public goods organize: The case of household refuse collection. Journal of Law, Economics, and Organization, 4(2), 217-241.

[10] Gardijan, M. and Škrinjarić, T. (2015). Equity portfolio optimization: A DEA based methodology applied to the Zagreb Stock Exchange. Croatian Operational Research Review, 6(2), 405-417.

[11] Hirsch, W. Z. (1965). Cost functions of an urban government service: Refuse collection. The Review of Economics and Statistics, 47, 87-92.

[12] Huang, Y.-T., Pan, T.-C. and Kao, J.-J. (2011). Performance assessment for municipal solid waste collection in Taiwan. Journal of Environmental Management, 92, 1277-1283.

[13] Ichinose, D., Yamamoto, M. and Yoshida, Y. (2013). Productive efficiency of public and private solid waste logistics and its implications for waste management policy. IATSS Research, Vol. 36, 98-105.

[14] lo Storto, C. (2013). Evaluating technical efficiency of Italian major municipalities: a data envelopment analysis model. Procedia - Social and Behavioral Sciences, 81, 346-350. 
[15] Moore, A., Nolan, J. and Segal, G. (2005). Putting out the trash: Measuring municipal service efficiency in U.S. cities. Urban Affairs Review, 41(2), 237259.

[16] Neralić, L. and Wendell, R. E. (2015). Generalized tolerance sensitivity and DEA metric sensitivity. Croatian Operational Research Review, 6(1), 169 180.

[17] Ozcan Yasar A. (2014). Health Care Benchmarking and Performance Evaluation. New York: Springer.

[18] Sherman, H.D., Zhu, J. (2006). Service Productivity Management. Improving Service Performance using Data Envelopment Analysis (DEA), New York Springer, ISBN: 978-0-387-33211-6,

[19] Stevens, B. J. (1978). Scale, market structure, and the cost of refuse collection. The Review of Economics and Statistics, 60(3), 438-448.

[20] Škuflić, L., Rabar, D. and Šokčević, S. (2010). Assessment of the efficiency of Croatian counties using data envelopment analysis. Economic ResearchEkonomska istraživanja, 23(2), 88-101.

[21] Thanassoulis, E. (2001). Introduction to the Theory and Application of Data Envelopment Analysis. Boston: Kluwer Academic Publishers.

[22] The Public Utilities Act. (2015). Available at: http://www.zakon.hr/z/319/ Zakon-o-komunalnom-gospodarstvu [Accessed 11/03/16].

[23] The Sustainable Waste Management Act. (2013). Available at: http://www. zakon.hr/z/657/Zakon-o-odr\%C5\%BEivom-gospodarenju-otpadom [Accessed $11 / 03 / 16]$.

[24] Vlahinić-Dizdarević, N. and Šegota, A. (2012). Total-factor energy efficiency in the EU countries. Zbornik radova Ekonomskog fakulteta u Rijeci - Proceedings of Rijeka Faculty of Economics, 30(2), 247-265.

\section{Appendix}

\begin{tabular}{|l|c|c|c|c|c|}
\hline Company name & $\begin{array}{c}\text { Total } \\
\text { assets }\end{array}$ & $\begin{array}{c}\text { Material } \\
\text { costs }\end{array}$ & $\begin{array}{c}\text { Costs of } \\
\text { employees }\end{array}$ & $\begin{array}{c}\text { Popula- } \\
\text { tion }\end{array}$ & EBITDA \\
\hline $\begin{array}{l}\text { BARANJSKA } \\
\text { ČISTOĆA D.O.O. }\end{array}$ & 832,072 & 246,641 & 493,247 & 39,420 & 328,928 \\
\hline $\begin{array}{l}\text { ČISTOĆA D.O.O. } \\
\text { KARLOVAC }\end{array}$ & $4,894,091$ & 787,773 & $1,668,834$ & 58,446 & 570,998 \\
\hline $\begin{array}{l}\text { ČISTOĆA I } \\
\begin{array}{l}\text { ZELENILO } \\
\text { D.O.O. }\end{array}\end{array}$ & 574,761 & 139,650 & 409,213 & 16,512 & 112,463 \\
\hline
\end{tabular}




\begin{tabular}{|c|c|c|c|c|c|}
\hline $\begin{array}{l}\text { DUGOSELSKI } \\
\text { KOMUNALNI I } \\
\text { PODUZETNIČKI } \\
\text { CENTAR D.O.O. }\end{array}$ & 635,005 & 407,553 & 310,325 & 17,466 & 101,017 \\
\hline $\begin{array}{l}\text { FLORA VTC } \\
\text { D.O.O. }\end{array}$ & $3,251,983$ & $3,883,376$ & $1,370,724$ & 39,679 & 360,597 \\
\hline $\begin{array}{l}\text { GKP PRE-KOM } \\
\text { D.O.O. }\end{array}$ & 974,160 & 583,783 & 477,842 & 24,157 & 131,604 \\
\hline $\begin{array}{l}\text { GOSPODARENJE } \\
\text { OTPADOM } \\
\text { SISAK D.O.O. }\end{array}$ & $2,775,738$ & 555,309 & 999,236 & 63,036 & 363,670 \\
\hline $\begin{array}{l}\text { INFRA-GRAD } \\
\text { D.O.O. }\end{array}$ & 694,553 & 69,339 & 137,742 & 4,323 & 146,499 \\
\hline KOMBEL D.O.O. & $3,407,168$ & 457,152 & 569,329 & 10,825 & 318,363 \\
\hline $\begin{array}{l}\text { KOMUNALAC } \\
\text { PETRINJA } \\
\text { D.O.O. }\end{array}$ & $2,805,509$ & 815,744 & $1,391,998$ & 24,671 & 277,087 \\
\hline $\begin{array}{l}\text { KOMUNALAC } \\
\text { VRBOVEC, } \\
\text { D.O.O. }\end{array}$ & $3,698,391$ & 408,881 & 738,347 & 28,360 & 34,876 \\
\hline $\begin{array}{l}\text { KOMUNALNO } \\
\text { HVAR D.O.O. }\end{array}$ & $6,739,750$ & 355,871 & 790,847 & 4,251 & 745,531 \\
\hline $\begin{array}{l}\text { KOMUNALNO } \\
\text { ODRŽAVANJE } \\
\text { D.O.O. }\end{array}$ & 373,230 & 103,773 & 575,071 & 13,396 & 212,199 \\
\hline $\begin{array}{l}\text { KOMUNALNO- } \\
\text { ZABOK D.O.O. }\end{array}$ & $1,200,989$ & 158,741 & 335,924 & 33,512 & 116,296 \\
\hline LUKOM - D.O.O. & $2,564,048$ & 207,323 & 322,160 & 8,478 & 152,749 \\
\hline $\begin{array}{l}\text { MAKARSKI } \\
\text { KOMUNALAC } \\
\text { D.O.O. }\end{array}$ & $1,400,732$ & 734,624 & $1,184,134$ & 13,834 & 153,998 \\
\hline PARK D. O. O. & $2,205,599$ & 300,356 & 381,223 & 6,462 & 157,876 \\
\hline $\begin{array}{l}\text { SLATINA KOM } \\
\text { D.O.O. }\end{array}$ & $1,938,875$ & 410,148 & 666,690 & 21,250 & $-10,460$ \\
\hline $\begin{array}{l}\text { VG ČISTOĆA } \\
\text { D.O.O. }\end{array}$ & $5,239,573$ & 481,561 & $1,656,704$ & 63,517 & 747,877 \\
\hline $\begin{array}{l}\text { VRANJEVO } \\
\text { D.O.O. }\end{array}$ & 201,672 & 167,087 & 155,753 & 6,343 & 17,088 \\
\hline
\end{tabular}

Source: Amadeus database, 2016

Table A1: Utility companies with corresponding input and output values 